\title{
Bilingual Dissection of Words with Biblical Correlation
}

\author{
James Xianxing Du \\ Independent Scholar, Tianjin, China
}

Email address:

Xx1du@yahoo.com

\section{To cite this article:}

James Xianxing Du. Bilingual Dissection of Words with Biblical Correlation. International Journal of Language and Linguistics. Vol. 7, No. 1, 2019, pp. 50-54. doi: 10.11648/j.ij11.20190701.17

Received: December 20, 2018; Accepted: January 11, 2019; Published: February 22, 2019

\begin{abstract}
In the language of China, GOD神 was initially written with two hands holding worshiping item. Its translated words related to GOD also show duality. We allocate the cause of such duality to the covenant of GOD with Abram, when "Abram brought all these to him, cut them in two and arranged the halves opposite each other". Astonishingly, we notice that numerous words match this verse and much more extensively, the whole holy bible including Genesis, Exodus, Leviticus and Numbers. We present examples of such matching to cutting offering, burning offering and divine appearance of LORD in cloud. The widespread coincidences of bi-linguistic match and biblical match can only be achieved by GOD.
\end{abstract}

Keywords: GOD, Bilingual Alignment, Biblical Match, Bible, Etymology

\section{Introduction}

In the last century, a common view in the linguistic field was that most abstract languages were phonetically generated according to accents. For instance, English language might be considered to simply combine letters that represented sound. Because of human invention of a considerable number of derived languages, people might have the misconception that the originally ancient languages were created by human beings alone, although bible claims divine split of human accents after great flood, in line with the sudden burst of languages worldwide except the earlier cuneiform form. For thousands of years linguists thought that the language of China contained mostly pictophonetic characters, and the phonetic part could only represent sound in many words [1]. Such assumption was largely derived from the difficulty in decoding etymology and inaccessibility of bible at ancient time. Hence, people could not realize that all words have semantic and theological origin and prior to biblical writing by Moses the language was already created to match bible in predestined way, as this testimony will testify for the first time in human history. This provides powerful and logical evidence for divine creation by GOD, and will have lasting effect on the faith and human civilization in the future.

\section{Results}

In the language of China, GOD 神 was initially written as
㔍 with two hands holding worshiping item. Notably, dignity, dogma, big, great and regime all contain duality too. In their structure, dogma has the affix do as double, dignity has the affix di as two, big has the affix bi as two, and regime and great have re as twice. The affixes can be written in either forward or backward direction. All these words share two features, a marker letter $\mathrm{G}$ (CT too; when $\mathrm{G}$ is split to $\mathrm{CT}$ ) next to an affix representing duality, such as do, di, du, bi and re. This is the feature for the holiest word GOD.

Why so many words include duality? This is closely related to how the initial chosen nation, Israel, worshiped GOD at the ancient time. In Genesis 15:10 for the covenant of GOD with Abram, "Abram brought all these to him, cut them in two and arranged the halves opposite each other" [2]. Astonishingly, we notice that numerous words matching this famous biblical verse. For instance, friend 伙伴 has 半 half and fire 火. Friend is not to share half of the fire, but to cut offering in halves and burn them on fire! 燎 burn and colleague 僚 have 脊 fire surrounding altar due to burnt worship. To observe is to serve both and sever bovine, and observation's translation 察 has to worship 祭. Several is to sever veal, to persevere 忍 is to sever with blade 刃, and severe is to sever again. Numerous words fit this way of duality, such as dissect, decide, differentiate, discern, discuss, consider, decipher, display, indicate, dedicate, conserve, preserve and so on. Dissect is to sect to two, 判 decide is to cut to halves 半, indicate and dedicate are to cut cattle to two, abdicate is not to cut to two, reveal is to cut veal to two, and serve 伺 has hand on altar ᄏิ 
this investigation proposes that in many words such as 僚 and 司, the affix 口 represents burnt altar.

In James 2:23-24 [3], ““'Abraham believed GOD, and it was credited to him as righteousness," and he was called GOD's friend. You see that a person is justified by what he does and not by faith alone." The other translation for friend, 友将录, has two hands. People thought that shaking hands was its etymology, but now we all know that its etymology includes raising both hands to worship GOD! High priest offered the service on behalf of people, and behalf has half, as he cut herds and flocks initially in halves. In Leviticus 14:31 [4] "the priest will make atonement before THE LORD on behalf of the one to be cleansed."

In contrast, if we look at rebellion 叛, it has re (halves), bell (bull) and no, and means not to cut bull in halves. It has 半 half and 反 oppose, as opposing "cut them in two and arranged the halves opposite each other" is considered the opponent. It was not created according to human logic-why only half action? Objecting cutting to two near altar is considered rebellion. A lot of words are created in this way and exhibit logical paradox if interpreted by human common sense, indicating that the languages can only be divinely designed in predestined way.

Birth 生 $\Psi \Psi \Psi$ has herd 牛 or flock羊 symbolized by two head horns on altar or bird spreading both wings on altar. This is derived from a very detailed decree in Leviticus 12:6-8 [4]. "When the days of her purification for a son or daughter are over, she is to bring to the priest at the entrance to the Tent of Meeting a year-old lamb for a burnt offering and a young pigeon or a dove for a sin offering." "These are the regulations for the woman who gives birth to a boy or a girl. If she cannot afford a lamb, she is to bring two doves or two young pigeons". Hence birth links to bird and has past perfect tense born pronounced burn of burnt offering. A pair of avian could be the etymology of the basic verb and auxiliary word have, and also the etymology of equivalent, equal avian altar. Not to worship in such pair, dis pair, will induce despair for worshipers. Repair is to cut in pair and put to burnt altar. Inspire and inspiration are in pair to spare sin. This is why priests were inspired to worship with full devotion, which contains dove in the regrouped form of devo, and devout is devo tuo, two doves on altar. In Luke 2:24 [5], after birth Joseph and Mary presented Jesus to THE LORD and offered a sacrifice in keeping with what is said in the law of THE LORD: "a pair of doves or two young pigeons", as written in Leviticus 12:8 [4]. Jesus Christ devoted Himself as divine offering, as described in 1 Corinthians 15:21-49 [6]. In Matthew 27:51 [7], "The curtain of the temple was torn in two from top to bottom." In Luke 23:33 [5], two criminals were co-crucified, "one on his right, the other on his left."

During Israelites' migration out of Egypt, it was noteworthy that only clean food listed in Leviticus 11 and Deuteronomy 14 were allowed to be eaten $[4,8]$, while a vast majority of edible sources were forbidden. As a result, the burnt offerings should have divided hoofs and be ruminant to digest twice, so that food is double hoof and digestion has DIG! Edible includes di E, divided hoof, as letter $\mathcal{E}$ represents hand. This is exactly why hoof 蹄 includes 帝 GOD. Hoof is dactyla in Latin with DAG. Flock and herd belong to artiodactyla. THE
LORD told Moses and Aaron to eat what "has a split hoof completely divided and that chews the cud" $[4,8]$, at a time when the Israelites were so starved and should grasp whatever could be reached along the route. The only reason is: this is from our LORD.

The fire 缭 winds around and curls up. To twine 缭/缠 entangles threads due to "finely twisted linen" worn by priest at burnt altar 田[9]. Far observation 瞭 is to observe such service in far遼 distance from tent 寮. 撩 could be to lift up fire or other worship related activity. When singing psalms, the voice is 嘹 loud and clear [10]. Fetter 镣 is also related to burnt altar due to bible. For instance, in Exodus 21:14 "But if a man schemes and kills another man deliberately, take him away from MY altar and put him to death." [9]

In Leviticus 1:6 and 4:11-12, an initial step in worship was peeling off leather [4]. "He is to skin the burnt offering and cut it into pieces". "But the hide of the bull and all its flesh, as well as the head and legs, the inner parts and offal - that is, all the rest of the bull- he must take outside the camp". This needs

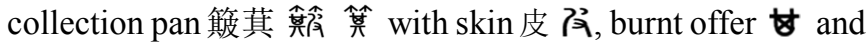
altar with division $\pi$. Trash is for ash, and rubbish is for burnt ash. Flame of ash flashes. Shabby is dressed when people removes ashes. Disheveled is dis shevel ed, away from shovel. Shake is to shake away ash. Burnt altar locates east to the Tent of Meeting, and the east seats worshipers to eat. Correspondingly east 東 has 田, burnt altar with copper grating. This is the biblical etymology of east.

In Maya language, ${ }^{2} \mathrm{j}$, previously thought to be related to east, also has divided offering 9 on burnt altar 9 bilingually match east 車's offering $\Varangle$ at altar $\ominus$. copper grating of burnt altar is included at higher frequency in Maya language. For instance, of can be considered as copper grating. thought in the past to be turtle shell, is likely not simply turtle but has overlaid bronze layer, the edge of altar and the edge of copper grating in triple layers $\mathbf{Q}$. In addition, it has copper grating with sacrificed pieces of offering, salt or incense powder $\%$, in full consistence with Leviticus [4]. Turtle has eltur of altar. Thus, for the first time in human history, this testimony proposes that Maya language also matches holy bible and other languages.

抚/摸 touch has 无/莫 no and hand. Why no is to touch? In Numbers 4:15 and 18:3, "Kohathites are to come to do the carrying. But they must not touch the holy things" [11]. "They are to be responsible to you and are to perform all the duties of the Tent, but they must not go near the furnishings of the sanctuary or the altar". Exodus 19:12 [9] required to put limits for the people around the mountain and tell them, "Be careful that you do not go up the mountain or touch the foot of it. Whoever touches the mountain shall surely be put to death." In Leviticus 15:19 and 22:4, "When a woman has her regular flow of blood, the impurity of her monthly period will last seven days, and anyone who touches her will be unclean till evening." "He will also be unclean if he touches something defiled by a corpse" [4].

In the above paragraphs, we randomly propose a number of words to demonstrate that words have biblical etymology, which will astonish the whole world so that we will not drift away from the fundamental biblical truth about divine creation 
of human beings and ancient languages. Next, we propose additional examples. There is a well known affix $⿴ 囗 十$ previously thought to represent farm, but extensive linguistic analysis indicates that this affix also represents burnt altar with copper grating, and is borrowed to represent creatures such as sacrificed ox. Ancient Egyptian and Maya languages may have similar structures that represent sacrificed offerings. Evidence also comes from English. When the two letters $\mathrm{O}$ and $\mathrm{X}$ in the word OX merge, it becomes $⿴ 囗 十$. 口represents burnt altar and + represents bronze grating, as described in Exodus 27:4 and 38:4 [9]. "They made a grating for the altar, a bronze network, to be under its ledge, half way up the altar." 知/智 knowledge has to know ledge of altar $\rightarrow \boxminus$, and pledge is for priest to pledge at ledge of altar. All regard acknowledging GOD! Understanding the grating of altar under ledge, we gratify and are grateful to HEAVENLY FATHER with full gratitude.

Now coincidence emerges. For eight words thin, think, thing, within, thunder, diagram, cat and fox, their corresponding words are 细, 思 or 慮, 物, 里, 雷, 画, 猫 and 狸. They either include ram, ox or the first half of cattle, or contain thi/un. Their matching words all include $⿴ 囗 十$ or 牛 ox! The two languages exhibit dramatic and extensive match in both meaning and affix distribution that is impossible to be explained by coincidences alone. Even alone exhibits this phenomenon, as alone and melon match 孤 and 瓜! In English, there are obvious vowel interchange, letter regrouping, letter rotation, and reversal in order, and we can give extensive examples, as amateur is amature, not mature, and precious is priceous. Melon is likely formed by $\mathrm{m}$ and lone, rather than me and lon. We predict that letter $\mathrm{m}$ means water here as melon is juicy.

Coincidences are everywhere in languages. Look at the word yellow 黄. If read in reversal, it is ow $\rightarrow$ ell $\rightarrow$ Y. Read from top to bottom, 黄 少 includes 廿 cow head and horns $\rightarrow$ 田 altar $\rightarrow$ 火 fire that contains $\mathrm{Y}$ if rotated $180^{\circ} \mathrm{C}$. With two fires 炎, offering $\psi$ and altar 日 in 崇, 僚/同工 fellow either burns bull and cow or carry poles I I together. These words were apparently created according to worship. 芬 fragrant has 份 fragment, as worshipers cut burnt offerings to fragments and in Leviticus priests shall burn them on the altar as an offering made by fire, an aroma pleasing to THE LORD [4]. 燔 burnt offering has the burnt altar with copper grating 田. 藩 foreign has igne of ignite and burnt altar with copper grating $⿴ 囗 十$. Lamb 羔 has … fire. The burnt offerings turn to black 黑霍 with burnt altar $\square$ and both affixes for fire, 火 and …. Therefore, the color of black is represented by the color of the burnt offering on altar after extensive fire, and the color of yellow is represented by the color of sacrificed ox! The organization of these words fits the Scripture fully well.

Furthermore, look at the words bellum, bullet, oven, diagram, bell and toll. Their matching words are 戰, 弹, 爐, 画 and 鐘, all including 田. Bellum has bull, cattle is in battle. Languages exhibit extensive match between languages, between a language and Bible, and among all the words. Languages guarantee that the whole world is in worship. Worship THE ALMIGHTY is worthy. The earliest work was worship, the earliest word was for worship, and the whole world has been in worship! World 界 consists of the sacrificed burnt offering at altar $⿴$ and worshiper 介. In Exodus 20:18-25, when "the people saw the thunder and lightning and heard the trumpet and saw the mountain in smoke, they trembled with fear." Then THE LORD asked Moses to make an altar of earth or stones [9]. Therefore, tremble 颤 and temple 壇 and shiver and shrine absolutely match each other! Trembling at worshiping place also occurred in Matthew 27:50-52 [7]. "And when Jesus had cried out again in a loud voice, He gave up His Spirit. At that moment the curtain of the temple was torn in two from top to bottom. The earth shook and the rocks split." In Acts 4:31, "After they prayed, the place where they were meeting was shaken" [12]. Another simplified translation for temple is 庙 that contains the offering at altar, although the majority of temples in China around that time strictly forbade shedding blood and sacrificing biological creatures. Logically, it fits the ritual in Old Testament rather than local religion and method of worship.

In Proverbs 9:10 [13], "The fear of THE LORD is the beginning of wisdom, and knowledge of THE HOLY ONE is understanding." Fear 畏 has burnt altar $\boxplus$ and worshiper. In Exodus 20:18-26, "When the people saw the thunder and lightning and heard the trumpet and saw the mountain in smoke, they trembled with fear". Moses said to the people, "Do not be afraid. GOD has come to test you, so that the fear of GOD will be with you". Immediately GOD asked the friar Moses to "Make an altar of earth for ME and sacrifice on it your burnt offerings" [9].

Why thin is related to worship? When we cut herd or flock to two and further into pieces, they are smaller, thinner or less. Priests cut offering to pieces to worship GOD for blessing. Piece is connected to peace, as real peace comes from SAVIOR. Only the Scripture can interpret why less is included in bless and bliss. By human being alone, it is impossible to create words in this way. Lesson 课 is no less, has the forbidden fruit 果, and can be interpreted as no cut and no blessing. Small and less, 小 and 少, mean cutting to two. Even the world famous ancient word interpretation book «Analytical Dictionary of Characters», written by Mr. Shen Xu approximately 1900 years ago in Han Dynasty, interpreted in this way [1]. Proxi 替, proximal and proximate are poir ox, pair ox.

If we look at bulletin, tell, born and cellar, their matching words 告示, 告, 生 and 窝 all include 生 ox and $\square$ altar. Stella 星 includes ox 牛 and matches tell too. Old testament instructed Hebrews to worship by offering herd or flock on burnt altar [4, 9], and the purpose of earliest bulletins likely included calling people to the Tent of Meeting and altar. This is exactly why bulletin includes bull! We predict that $\mathrm{T}$ could represent burnt altar. If we reverse the third to sixth letters, bulletin becomes tell. This is also exactly why meet sounds similar to meat, the meat for burnt offering that was often eaten after the worship. Tow and pull 牵 has this altar $\mapsto$, as priests pull and tow bull and cow 牛 to the north or near the altar to be slaughtered and the cut pieces were burnt on altar [4].

Chiefs of the earliest tribes around the world were typically high priests. This is the biblical basis for why chief is similar 
to chef and rabbi is similar to barbecue. President contains priest. Profession is to pro confess sin. 將 leader has one side of flock or herd 片 and an affix of meat 夕 offered by human hand $\lambda$. In Hebrews 4-10, Jesus Christ is the "great high Priest" and "designated by GOD to be high Priest in the order of Melchizedek" [14]. Thus, let us hold firmly to the faith we profess! "The priest who offers it shall eat it; it is to be eaten in a holy place, in the courtyard of the Tent of Meeting", as written in Leviticus 6:26, 7:6, 7:15 and 22:30 [4]. And "it must be eaten in a holy place; it is most holy" and "meat of his fellowship offering of thanksgiving must be eaten on the day it is offered". For thank offering, "it must be eaten that same day". Some meat was priests' share. Leviticus 7:30-35 required the priests to "wave the breast before THE LORD as a wave offering", and "the breast belongs to Aaron and his sons." "You are to give the right thigh of your fellowship offerings to the priest as a contribution." "This is the portion of the offerings made to THE LORD by fire that were allotted to Aaron and his sons", and "THE LORD commanded that the Israelites give this to them as their regular share" [4]. This is exactly why wag and wage are related, as the indicated meat that these priests wagged was their regular wage!

Carnivore 莗 contains 軍 army and burnt altar 田, and army has not only Moses' arm but also ram. Why? Hebrews ate their sacrificed offerings, and walked out of Egypt together with their flocks and herds as the army of GOD [9]. In Exodus 10:9 and 12:31-42, Moses answered, "We will go with our young and old, with our sons and daughters and with our flocks and herds, because we are to celebrate a festival to THE LORD." "The Israelites journeyed from Rameses to Succoth. There were about six hundred thousand men on foot, besides women and children. Many other people went up with them, as well as large droves of livestock, both flocks and herds." Because they crossed Red sea with flocks and herds, sea, marine and the Greek maria's matching word 洋 has ram 羊. "At the end of the 430 years, to the very day, all THE LORD’s divisions left Egypt.”輿炼 is four hands to carry burnt altar during this long march.

Because GOD arrives in cloud, we perform bi-linguistic alignment analysis for the term of cloud between the two languages. Interestingly, we can interpret cloud as dou $+1+c$, double + line + curve to perfectly match cloud 云, with $\overline{\bar{\sigma}}$ as its seal version utilized two millenniums ago. The top two lines $=$ are double lines of cloud. Curve $v$ is rising cloud. In Exodus 40:34-38 [9], "Then the cloud covered the Tent of Meeting, and the glory of THE LORD filled the Tabernacle. Moses could not enter the Tent of Meeting because the cloud had settled upon it". Thus, 会 Meeting has cloud 云 and Tent $\wedge$. The altar is right in front of the Tabernacle. The cloud settles right upon it when LORD 帝 (商 as its seal version utilized two millenniums ago) arrived.

Thus, we can interpret the line (s) on the top of GOD 帝(彩 as its bone version used more than three millenniums ago) as cloud. The rest of this word contains firewood for burning offering on altar. In Exodus 25:8 and 33:9 "Moses went into the tent, the pillar of cloud would come down and stay at the entrance, while THE LORD spoke with Moses. Whenever the people saw the pillar of cloud standing at the entrance to the tent, they all stood and worshiped, each at the entrance to his tent." Include could be in cloud. Exclude is outside cloud.
Preclude is in front of cloud, as in Exodus 40:35-37 "Moses could not enter the Tent of Meeting because the cloud had settled upon it, and the glory of THE LORD filled the tabernacle." If "the cloud did not lift, they did not set out" [9]. In 1 Kings 8:10-11 "cloud filled the temple of THE LORD. And the priests could not perform their service because of the cloud, for the glory of THE LORD filled HIS temple." [15]

Because Jesus transfigured on mountain in cloud $[5,7,16]$, Child 孩 contains son 子 and cloud 亥 $\overline{\overline{4}} \overline{\bar{\pi}} \overline{\mathrm{C}}$ is cloud, including two lines and a curve. $\boldsymbol{\gamma}$ is human. Sometimes cloud is represented by only one to two lines or a curve. Child has dilc - two lines and a curve. In Matthew 17:2-6 and Mark 9:2-7 "While He was still speaking, a bright cloud enveloped them, and a voice from the cloud said, "This is MY Son, whom I love; with Him I AM well pleased. Listen to Him!"'” [7, 16]. In Luke 9:28-36, "Two men, Moses and Elijah, appeared in glorious splendor, talking with Jesus. They spoke about His departure, which He was about to bring to fulfill at Jerusalem." "While He was speaking, a cloud appeared and enveloped them, and they were afraid" [5]. \$s can be considered Moses and Elijah or disciples, and $力$ would be Jesus. In summary, child is LORD's Child under cloud.

\section{Discussion}

In this article, for the first time in human civilization languages are proposed to have biblical etymology. In other words, holy bible is the decoding book for discovering the semantic origin of words in languages. GOD is DIRECTOR and DICTATOR in divinity and dignity, giving all the correct doctrines and regulations to physical and spiritual Israelites. Prophets predict. Prodigy is talent from GOD. Dictionaries, digits and dicta in Proverbs reflect the wisdom of GOD, and rectitude, cognition and conduct are guided and judged by GOD. The purpose of life is to register to the Book of life, and true credit is to trust in GOD. Even Bible is composed of duality, the old and new testaments.

We notice that each English letter in a word has meaning in addition to representing sound and forms a hieroglyphic substructure and semantic unit for the word. In other words, we can guess the meaning of a word through its affixes and substructures without knowing its pronunciation. With bi-linguistic alignment or biblical match, we will be able to decode the meaning of many words. This is likely the main way to decode Maya language. Since the majority of words were created from spoken languages, these indicate that during the time of spoken languages, pronunciation had been prearranged in predestined way to match the written versions to allow widespread coincidences, after GOD decided to "confuse their language so they will not understand each other" in Genesis 11:7 [2]. GOD checks and balances mankind.

This article proposes new affixes and provides novel meanings to existing affixes such as 口 and 田. 口 was considered as mouth in the past, but in many cases it represents altar or stones that build the altar. 田 was considered as farm in the past, but in most cases it represents burnt altar according to current analysis. This article also proposes one or two lines to represent the divine cloud 
descried in bible. In addition to such surprises in etymology, a lot of words fit holy bible in meaning but exhibit logical paradox if interpreted by human common sense, indicating that languages are from divine design.

In consistence of bible, tribe leaders were typically worshipers. Parishioners and parsons cut in pair at biblical parish, and cutting offerings to halves to behave is the favored behavior. In ancient time, chiefs of tribes were typically high priests burning offerings, so that chef and chief are related words. Two commonly recognized ancestors for China, 炎 and 黄, were either full of fire 火 or have ox on burnt fire. They were both from a tribe called “have bear" 有熊. 有 contains hand above sacrificed meat, and 熊 originally meant burning fire, a ritual of worship that fully matches biblical description. These two ancestors and the third ancestor 虫尤 fought around the province 冀, both hands with offering 共 and burnt altar with grating $⿴ 囗 十$. Therefore, the people and place on the other side of planet earth have biblical etymology. The language of China does not fully reflect its own tradition and culture, but exhibits full coherence to biblical description. The two sides of earth demonstrate identical pattern and mutual match between Holy Bible and languages, a phenomenon that can only be considered as miracles.

\section{Conclusion}

Holy bible recorded extremely detailed historical events and decrees, and these regulations and records are extensively matched by languages with systematic biblical correlation in semantic origin, although this article only provides some examples due to space restriction. Eden Garden, Red sea, relatives, Jacob, Health, flesh, liquid, animal, business, construction, direction, shape, color, textile, seven days... Everything fits! Statistically, the widespread coincidence of bi-linguistic match and biblical match is impossible to be achieved by nature alone, indicating that CREATOR either initially created the ancient languages directly or guided human mind to create languages such as English as one of the greatest spiritual miracles.

\section{Acknowledgements}

We are grateful to THE LORD CREATOR of heavens and earth with full gratitude in highest regards.

\section{References}

[1] «Analytical Dictionary of Characters» written by Shen Xu in Han dynasty.

[2] The Book of «Genesis» in Holy Bible (New International Version).

[3] The Book of «James» in Holy Bible (New International Version).

[4] The Book of «Leviticus» in Holy Bible (New International Version).

[5] The Book of «Luke» in Holy Bible (New International Version).

[6] The Book of «1 Corinthians» in Holy Bible (New International Version).

[7] The Book of «Matthew» in Holy Bible (New International Version).

[8] The Book of «Deuteronomy» in Holy Bible (New International Version).

[9] The Book of «Exodus» in Holy Bible (New International Version).

[10] The Book of «Psalms» in Holy Bible (New International Version).

[11] The Book of «Numbers» in Holy Bible (New International Version).

[12] The Book of «Acts» in Holy Bible (New International Version).

[13] The Book of «Proverbs» in Holy Bible (New International Version).

[14] The Book of «Hebrews» in Holy Bible (New International Version).

[15] The Book of «1 Kings» in Holy Bible (New International Version).

[16] The Book of «Mark» in Holy Bible (New International Version).

[17] «The Advanced learner's Dictionary of Current English with Chinese Translation» by Oxford University Press. 